\title{
EFFECTS OF GREEN TEA (Camellia sinensis) ON PARACETAMOL-INDUCED OXIDATIVE STRESS MARKERS IN WISTAR RATS
}

\author{
Ezeja, E. P., ${ }^{1}$ Onuoha, N.O. ${ }^{1}$ and Ufere, E.A. ${ }^{1}$ \\ ${ }^{1}$ Department of Nutrition and Dietetics. Faculty of Agriculture, University of Nigeria, Nsukka.
}

\section{Corresponding author's email: peace.ezeja@unn.edu.ng}

\begin{abstract}
Background: Green tea is a good source of phenolic compounds which are known to possess antioxidant properties. Although there have been researches on the effect of fresh green tea leaves on oxidative stress, there is paucity of data on processed green teas consumed in Nigeria.

Objective: This study was conducted to determine the effect of green tea on oxidative stress biomarkers in Adult male Wister rats.

Methods: Serum malondialdehyde (MDA) level, catalase (CAT), superoxide dismutase (SOD), glutathione peroxidase (GPx), vitamins A, C and E activity of rats treated with green tea extract (GTE) were determined using standard methods. Thirty two (32) rats were divided into six groups of five rats each. Group 1 fed only on normal rat chow. All groups except group I were oxidative stress induced with $1500 \mathrm{mg} / \mathrm{kg}$ body weight (bw) of paracetamol orally for three consecutive days. Group 2 did not receive any treatment. Group 3 was treated with ascorbic acid (20mg/kg bw) for seven consecutive days while groups 4 to 6 were treated with $50,100,200 \mathrm{mg} / \mathrm{kg}$ bw of GTE respectively for seven consecutive days.

Results: There was a significant $(\mathrm{p}<0.05)$ decrease in the MDA concentration in groups 4 to 6 compared with groups 1 to 3 . Group 5 had the highest SOD activity while group 2 recorded the highest CAT activity. However the GPx activity showed non-significant $(p>0.05)$ difference among all the groups. The vitamin A level of the groups 4 to 5 showed a significant $(\mathrm{p}<0.05)$ decrease compared with groups 1 to 3 . However, vitamin $\mathrm{C}$ and $\mathrm{E}$ levels of groups 5 increased significantly $(\mathrm{p}<0.05)$ compared with group 2.

Conclusion: GTE consumption at $50,100,200 \mathrm{mg} / \mathrm{kg}$ bw for seven consecutive days caused reduction in serum MDA level and increased serum enzymatic and non-enzymatic antioxidants in rats.
\end{abstract}

Keywords: Green tea, paracetamol, oxidative stress.

\section{INTRODUCTION}

Free radicals are molecular species that are capable of existing independently and known to be electron donors or acceptors (1). They possess unpaired electrons in their atomic orbit and this causes them to accept electrons from other molecules to neutralize themselves. As a result of the unpaired electrons, free radicals are highly reactive and unstable species and are able to damage essential biological molecules such as DNA, proteins, carbohydrates, and lipids in the nucleus and in the membranes of cells (2). They attack healthy cells of the body and thus their structure and functions are lost in the process. This consequently leads to cell damage and homeostatic disruption. Free radicals are consistently produced in the cells of the body as a result of normal cellular function. This happens when oxygen is metabolized in the cells. Excessive accumulation of free radicals in the body from internal and external sources is detrimental to health and leads to oxidative stress (2).

Oxidative stress is a condition which results when the production of free radicals and their active intermediates in a system surpasses the ability of the system to counteract and remove them from itself (3). Oxidative stress has been implicated in various diseases which include malaria, atherosclerosis, rheumatoid arthritis, chronic fatigue syndrome and neurological diseases such as Parkinson's disease and Alzheimer's disease (4). It is also implicated in diabetes and is likely to be involved in age-related development of cancer (5).

The generation and destructive oxidative actions of free radicals in the body can be controlled naturally by various beneficial compounds known as antioxidants. The damages cause by free radicals becomes outrageous only when there is a short supply of antioxidants in the system. In order to cope with the oxidative damages by free radicals, the body has naturally developed a complex antioxidant defense system (2). However, this defense system may be outweighed by several pathological or environmental factors. In which case, a fragment of a free radical may survive being destroyed and cause more radicals to be formed. This necessitates the need to supply other exogenous sources of antioxidants through diet.

Green tea is a popular beverage processed from the plant Camellia sinensis without fermentation. It is a frequently consumed beverages all over the world (6). Its origin can be traced to Asia and it is presently been cultivated in more than thirty nations of the world (7) including Nigeria (8). Green tea is considered to possess the most effective antioxidant activity among the other tea types produced from the 
same plant (9). This property is due to its high concentration of antioxidant phytochemicals.

Polyphenolic compounds are the main phytochemicals in Camellia sinensis plant (10). There have been increasing scientific interest on polyphenols as a result of their possible effects which are advantageous to human health. The flavonols known as catechins are the most abundant polyphenol in green tea. Green tea catechins include epigallocatechin-3- gallate (EGCG), epigallocatechin (EGC), epicatechin-3-gallate (ECG) and epicatechin (EC) (11). Epigallocatechin3 - gallate (EGCG) accounts for about $59 \%$ of all the green tea catechins (7). EGCG possesses various biological activities including anti-inflammation activities and also act as a potent antioxidant (11).

Paracetamol also known as acetaminophen is one of the most commonly used over-the-counter pain reliever and antipyretic drugs across the world when used at therapeutic doses. Excessive intake of paracetamol can cause severe liver injury, kidney damage and liver necrosis in human beings and animals (12). Paracetamol is converted by certain enzymes to N-acetyl-P-benzoquinoneimine (NPQI) which is a highly toxic metabolite which can cause oxidative stress and depletion of glutathione leading to hepatotoxicity (13). Administration of $1500 \mathrm{mg} / \mathrm{kg}$ body weight for three consecutive days was also reported to have induced oxidative stress/hepatotoxicity in rats (14). Therefore, the aim of this work was to determine the effect of green tea as a source of antioxidants on paracetamol-induced oxidative stress in adult Wister rats.

\section{MATERIALS AND METHODS Study Design}

This study employed experimental study design. This is a scientific research approach with different sets of variables where one of them is kept constant and used to quantify the changes in the other variables.

\section{Purchase of Green Tea Sample}

A commercially available green tea brand (Legend green tea) was purchased from Ogige Market, Nsukka in Nsukka Local Government Area, Enugu State, Nigeria and used for the study.

\section{Infusion}

The green tea infusion was prepared using the procedure described by Safdar, Sarfaraz, Kazmi and Yasmin (15) as soft infusion method. A tea bag of $2 \mathrm{~g}$ was weighed and dipped into $100 \mathrm{mls}$ of distilled water at $80^{\circ} \mathrm{C}$ for 5 minutes.

\section{Sourcing and Housing of Animals}

Thirty adult Wister rats weighing between 98-123 g were purchased from Dr Emeka Nwankwo's rat breeding farm around University of Nigeria, Nsukka. The rats were randomly divided into six groups of five rats each, with $\pm 5 \mathrm{~g}$ as the accepted difference in weight of the rats in each cage. These rats were maintained under normal environmental conditions in Twin Vet Resource Animal Laboratory, Obukpa, Nsukka, Enugu state, Nigeria.

\section{Experimental Design}

The rats were fed on rat chow and water ad libitum. They were left to acclimatize to the laboratory conditions for 3 days at room temperature $\left(25 \pm 2^{\circ} \mathrm{C}\right)$ prior to commencement of the experiment. The study was conducted for a period of 14 days consisting of the 3 days of acclimatization, 3 days for the inducement of oxidative stress in rats (inducement was done using paracetamol $1500 \mathrm{mg} / \mathrm{kg}$ body weight (bw) orally) and 7 days for the administration of the different doses of the sample. The last day was for fasting prior to blood sample collection. The study rats were categorized thus:

Table 1: Designed Chart for Green Tea administration

\begin{tabular}{|c|c|c|c|c|}
\hline Groups & $\begin{array}{c}\text { Treatment/Quantity } \\
\text { of Green Tea } \\
\text { Extract ( } \mathrm{mg} / \mathrm{kg} \mathrm{bw})\end{array}$ & Number of Rats & Feeding Period & $\begin{array}{c}\text { Oxidative Stress } \\
\text { Inducement }\end{array}$ \\
\hline 1(normal control) & $\mathrm{AF}+$ water & 5 & 7 & Was not done \\
\hline 2(treatment control) & $\mathrm{AF}+$ water & 5 & 7 & Was done \\
\hline 3(standard control) & $\mathrm{AF}+$ water $+\mathrm{Asc}$ & 5 & 7 & Was done \\
\hline $\begin{array}{l}4 \text { (experimental } \\
\text { group) }\end{array}$ & 50 & 5 & 7 & Was done \\
\hline $\begin{array}{l}5 \text { (experimental } \\
\text { group) }\end{array}$ & 100 & 5 & 7 & Was done \\
\hline $\begin{array}{l}6 \text { (experimental } \\
\text { group) }\end{array}$ & 200 & 5 & 7 & Was done \\
\hline
\end{tabular}

GT = Green Tea $;$ BW = Body Weight AF = Animal Feed Asc=Ascorbic acid 
The rats were subjected to fasting ( 24 hours) a day to the blood collection. Blood samples were collected from the rats through the ocular puncture for biochemical indices determination on the last day of the experiments. The rats used for the study were sacrificed after blood sample collection. The blood samples were put in non - heparinized sample bottles for the biochemical test. The blood samples were used for the analysis of serum malondialdehyde (MDA) level, catalase (CAT), superoxide dismutase (SOD), glutathione peroxidase (GPx), vitamins A, C and E activity.

\section{Lipid Peroxidation (Malondialdehyde Level) Determination}

Lipid peroxidase in the supernatant fractions was determined spectrophotometrically by assessing the level of Thiobarbituric acid reactive substances (TBARS) as described by Varshney and Kale (16). The result was expressed in malondaidehyde (MDA) formed relative to an extinction coefficient of $1.5 \times 10^{6} \mathrm{~mol} / \mathrm{cm}$. Into a test tube, 0.4 of the serum was mixed with $1.6 \mathrm{ml}$ of $0.15 \mathrm{~m}$ Tris $\mathrm{KCl}$ buffer followed by addition of $0.5 \mathrm{ml}$ of $20 \%$ Thiobarbituric acid (TCA). $0.5 \mathrm{ml}$ of $52 \mathrm{mM}$. TBA was added and the mixture was placed in a water bath for 45 minutes at $80^{\circ} \mathrm{C}$ at the expiration of incubation time, the mixture was allowed to cool and centrifuged at $3000 \mathrm{rpm}$ for 10 minutes. The absorbance of the clear supernatant was measured against a reference blank of distilled water at $532 \mathrm{~nm}$. The concentration of MDA in each sample was gotten by dividing the absorbance with the molar extinction coefficient.

\section{Determination of Enzymatic Antioxidant Parameters}

\section{Determination of Catalase (CAT) Activity}

The serum catalase activity was determined according to the method of Singh (17). $\mathrm{H}_{2} \mathrm{O}_{2}$ solution (4 ml) was added to $5 \mathrm{ml}$ of phosphate buffer followed by the addition of $1 \mathrm{ml}$ of the serum. The mixture was gently mixed at room temperature. A portion $(1 \mathrm{ml})$ of the reaction mixture was withdrawn and blown into $2 \mathrm{ml}$ dichromate/acetic acid reagent at one-minute intervals and the steady absorbance reading was taken at $570 \mathrm{~nm}$.

\section{Calculation of Result}

The monomolecular velocity constant $\mathrm{K}$; for the decomposition of hydrogen peroxide by catalase was determined by using the equation for a firstorder reaction

$\mathrm{K}=\frac{1}{\mathrm{t}} \log \frac{\mathrm{so}}{\mathrm{S}}$

Where $\mathrm{SO}$ is the initial $\mathrm{H}_{2} \mathrm{O}_{2}$ concentration and $\mathrm{S}$ is the concentration of $\mathrm{H}_{2} \mathrm{O}_{2}$ at a particular time interval given as $t$ (minutes). The values of $\mathrm{K}$ are plotted against $\mathrm{t}$, and the velocity constant of catalase $\mathrm{K}$ (o) at $\mathrm{O}$ minute determined by extrapolation (that is the intercept on the vertical axis).

\section{Determination of Superoxide Dismutase (SOD)} Activity

This was determined as described by Fridovich (18). The assay was performed by measuring $0.2 \mathrm{ml}$ of the serum into a test tube and then, $0.5 \mathrm{ml}$ of $0.05 \mathrm{M}$ phosphate buffer ( $\mathrm{pH} 7.8$ ) was added. The mixture was equilibrated in the spectrophotometer before adding adrenaline solution. The reaction started with the addition of $0.3 \mathrm{ml}$ of freshly prepared adrenaline solution to the mixture followed by quick mixing by inversion in the cuvette. The reference cuvette therefore contained $2.5 \mathrm{ml}$ buffer, $0.3 \mathrm{ml}$ of adrenaline and $0.2 \mathrm{ml}$ of serum. The increase in absorbance was taken at $480 \mathrm{~nm}$ for 150 seconds at 30 seconds interval.

Increase in absorbance per minute $=\frac{\mathrm{A}_{3}-\mathrm{A}_{\mathrm{O}}}{2.5}$

Where $\mathrm{A}_{\mathrm{O}}=$ absorbance after 30 seconds

$\mathrm{A}_{3}=$ absorbance after 15 second

$\%$ Inhibition $=100-($ increase in absorbance for substrate $) \times 100$ (Increase in absorbance for blank)

One unit of SOD activity was given as the amount of SOD necessary to cause $50 \%$ inhibition of the oxidation of adrenaline.

Note: A blank was prepared with $0.3 \mathrm{ml}$ of adrenaline in $2.5 \mathrm{ml}$ of buffer.

\section{Glutathione Peroxidase Determination}

This was based on the method of Jollow, Mitchell, Zampaglione and Gillette (19). To $1 \mathrm{ml}$ of the serum, equal volume of $4 \%$ sulfo-salicyclic acid was added to deproteinize the serum. The mixture was centrifuged at $17,000 \mathrm{rpm}$ for 15 minutes at $2^{\circ} \mathrm{C}$. Supernatant $(0.5 \mathrm{ml})$ was added to $4.5 \mathrm{ml}$ of Ellman's reagent. A blank was prepared by adding $0.5 \mathrm{ml}$ of $4 \%$ sulfo-salicyclic to $4.5 \mathrm{ml}$ Ellman's reagent. The absorbance was read at $412 \mathrm{~nm}$ and the equivalent GSH concentration was read from the curve.

Activity of Glutathione Peroxidase $=\frac{\mathrm{DOD}}{\mathrm{K}} \times \frac{10}{1}$

Where DOD $=$ change in optical density or absorbance $\mathrm{K}=$ constant $(0.021)$

\section{Determination of Non-Enzymatic Antioxidant Parameters Determination of Vitamin A}

Retinol concentration was analyzed by UV inactivation as described by Bassey, Lowry, Block and Lopez (20) using 180 $\mu$ l serum. By this method, since saponification was involved both retinol binding protein (RBP)-bound retinol and retinyl esters were measured together. Total carotenoid was determined in the same sample by measuring their spectrophotometric absorbance at 460nm.

\section{Calculation}

Concentration of the sample $=$

Absorbance of the sample $X$ concentration of standard Absorbance of standard 


\section{Determination of Serum Ascorbic Acid (Vitamin C) Concentration}

This was performed using the dinitrophenyl hydrazine method as outline by Block et al. (21). Test sample $(1 \mathrm{ml})$ was pipetted into a test tube followed by $1 \mathrm{ml}$ of $10 \mathrm{~g} / \mathrm{dl}$ trichloroacetic acid. The content of the tube was mixed thoroughly and centrifuged for 5 minutes at 3000rpm. Supernatant $(1 \mathrm{ml})$ was pipetted into another tube followed by $0.4 \mathrm{ml}$ colour reagent. Standard and water (blank) was put through the same procedure. They were cooled in an ice bath for 5 minutes after which $2.0 \mathrm{ml}$ of ice cold, $85 \%$ of sulphuric acid was added to each tube, slowly with mixing. The absorbance was read against the blank in the spectrophotometer at $450 \mathrm{~nm}$.

Concentration of the sample $=$

Absorbance of the sample X concentration of standard Absorbance of standard

\section{Determination of Vitamin $\mathbf{E}$}

This was performed by the method of Baker, Frank \& Angelis (22). Serum $(0.1 \mathrm{ml})$ was pipetted into a test tube and $0.9 \mathrm{ml}$ of distilled water was added. One milliliter $(1 \mathrm{ml})$ of $0.2 \%$ ferric chloride and $1 \mathrm{ml}$ of alcohol $0.5 \% \alpha, \alpha$-bipyridyl solutions was added. The mixture was vortexed and diluted to $5 \mathrm{ml}$ with distilled water. The absorbance was read at 520nm.

Concentration of the sample $=$ Absorbance of the sample X concentration of standard

Absorbance of standard

\section{Data Analysis}

The data obtained were subjected to statistical analysis using Statistical Package for Social Sciences (SPSS) version 23. Descriptive statistics (mean and standard deviation) was used to describe the data. The means of test groups were compared using Analysis of Variance (ANOVA). Statistical significance was accepted at $\mathrm{p}<0.05$.

\section{RESULTS}

Table 2 shows the results of the effect of green tea on the malondialdehyde concentration (MDA), superoxide dismutase (SOD), catalase (CAT) and glutathione peroxidase (GPx) activities in adult Wistar rats. It was observed that a significant $(p<0.05)$ decrease occurred in the malondialdehyde concentration of group 2 (treatment control) $(0.27 \pm 0.05 \mathrm{mg} / \mathrm{dl})$ when compared with the experimental groups 4,5 and $6 \quad(0.16 \pm 0.05$, $0.15 \pm 0.03,0.12 \pm 0.12 \mathrm{mg} / \mathrm{dl})$, respectively. The superoxide dismutase activity of the treatment control group showed a significant $(\mathrm{p}<0.05)$ decrease when compared to the experimental groups. Also, a significant $(\mathrm{p}<0.05)$ increase also occurred in the catalase activity of the experimental groups when compared with the normal control groups. However, the result of the glutathione peroxidase activity showed non-significant $(p>0.05)$ difference among all the groups.

Table 2: Effects of Green Tea on Malondialdehyde concentration (MDA), superoxide dismutase (SOD), catalase (CAT) and glutathione peroxidase (GPX) activities in adult Wistar rats.

\begin{tabular}{cllllll} 
Parameters & $\begin{array}{l}\text { Group } \\
\text { 1(normal } \\
\text { control) }\end{array}$ & $\begin{array}{l}\text { Group 2 } \\
\text { (treatment } \\
\text { control) }\end{array}$ & $\begin{array}{l}\text { Group } \\
\text { 3(standard } \\
\text { control) }\end{array}$ & $\begin{array}{l}\text { Group } \\
\text { 4(experimental } \\
\text { group) }\end{array}$ & $\begin{array}{l}\text { Group } \\
\text { 5(experimental } \\
\text { group }\end{array}$ & $\begin{array}{l}\text { Group } \\
\text { 6(experimental } \\
\text { group }\end{array}$ \\
\hline $\begin{array}{c}\text { MDA } \\
\text { (mg/dl) }\end{array}$ & $0.17 \pm 0.07^{\mathrm{a}}$ & $0.27 \pm 0.05^{\mathrm{b}}$ & $0.18 \pm 0.04^{\mathrm{a}}$ & $0.16 \pm 0.05^{\mathrm{a}}$ & $0.15 \pm 0.03^{\mathrm{a}}$ & $0.12 \pm 0.12^{\mathrm{a}}$ \\
$\begin{array}{c}\text { SOD } \\
(\mathbf{I U} / \mathbf{L})\end{array}$ & $10.76 \pm 0.46^{\mathrm{a}, \mathrm{b}}$ & $10.49 \pm 1.08^{\mathrm{a}}$ & $11.16 \pm 0.22^{\mathrm{a}, \mathrm{b}}$ & $11.18 \pm 0.22^{\mathrm{a}, \mathrm{b}}$ & $11.35 \pm 0.11^{\mathrm{b}}$ & $11.07 \pm 0.18^{\mathrm{a}, \mathrm{b}}$ \\
$\mathbf{C A T}(\mathbf{I U} / \mathbf{L})$ & $1.72 \pm 0.21^{\mathrm{b}}$ & $2.82 \pm 0.38^{\mathrm{d}}$ & $1.96 \pm 0.61^{\mathrm{b}, \mathrm{c}}$ & $1.97 \pm 0.30^{\mathrm{b}, \mathrm{c}}$ & $2.32 \pm 0.42^{\mathrm{c}, \mathrm{d}}$ & $1.15 \pm 0.17^{\mathrm{a}}$ \\
GPx (IU/L) & $26.33 \pm 1.84^{\mathrm{a}}$ & $27.25 \pm 0.68^{\mathrm{a}}$ & $26.01 \pm 1.00^{\mathrm{a}}$ & $25.74 \pm 1.17^{\mathrm{a}}$ & $25.94 \pm 0.81^{\mathrm{a}}$ & $26.65 \pm 0.63^{\mathrm{a}}$ \\
\hline
\end{tabular}

Mean \pm SD $(n=5)$. Values in the same row bearing different superscript letters were significantly different $(p<0.05)$ while values in the same row bearing the same superscript letters were not significantly different $(p>0.05)$.

Table 3 shows the results of the effect of green tea on non- enzymatic antioxidant vitamins (A, C, E) parameters in adult Wistar rats. A significant $(\mathrm{p}<$ 0.05 ) decrease was observed in vitamin $\mathrm{A}$ concentration of all the experimental groups compared to control groups. There was nonsignificant $(p>0.05)$ difference in the vitamin $C$ concentration of the experimental groups when compared with the control groups, except group 5 which increased significantly $(p<0.05)$ from all the other groups. Vitamin $\mathrm{E}$ concentration of experimental groups 5 and 6 were significantly $(\mathrm{P}<0.05)$ higher than those of the control groups. However, no significant $(\mathrm{P}>0.05)$ difference was observed in group 4 when compared to the control groups. 
Table 3: Effects of Green Tea on the levels of serum non- enzymatic antioxidant vitamins (A, C, E) parameters in adult Wistar rats.

\begin{tabular}{|c|c|c|c|c|c|c|}
\hline $\begin{array}{c}\text { Parameters } \\
\text { (mg/dl) }\end{array}$ & $\begin{array}{l}\text { Group } \\
1 \text { (normal } \\
\text { control) }\end{array}$ & $\begin{array}{l}\text { Group } 2 \\
\text { (treatment } \\
\text { control) }\end{array}$ & $\begin{array}{l}\text { Group } \\
3 \text { (standard } \\
\text { control) }\end{array}$ & $\begin{array}{l}\text { Group } \\
\text { 4(experimental } \\
\text { group) }\end{array}$ & $\begin{array}{l}\text { Group } \\
5 \text { (experimental } \\
\text { group }\end{array}$ & $\begin{array}{l}\text { Group } \\
\text { 6(experimental } \\
\text { group }\end{array}$ \\
\hline Vitamin A & $20.57 \pm 1.82^{b, c, d}$ & $22.52 \pm 1.56^{\mathrm{d}}$ & $21.56 \pm 2.85^{\mathrm{c}, \mathrm{d}}$ & $18.80 \pm 1.80^{\mathrm{a}, \mathrm{b}, \mathrm{c}}$ & $18.43 \pm 1.88^{\mathrm{a}, \mathrm{b}}$ & $17.21 \pm 1.03^{\mathrm{a}}$ \\
\hline Vitamin C & $0.49 \pm 0.09^{\mathrm{a}}$ & $0.59 \pm 0.18^{\mathrm{a}}$ & $0.52 \pm 0.08^{\mathrm{a}}$ & $0.65 \pm 0.22^{\mathrm{a}}$ & $0.91 \pm 0.17^{\mathrm{b}}$ & $0.58 \pm 0.11^{\mathrm{a}}$ \\
\hline Vitamin E & $1.29 \pm 0.11^{\mathrm{a}}$ & $1.26 \pm 0.02^{\mathrm{a}}$ & $1.27 \pm 0.10^{\mathrm{a}}$ & $1.36 \pm 0.02^{\mathrm{a}}$ & $1.86 \pm 0.15^{\mathrm{b}}$ & $1.99 \pm 0.13^{c}$ \\
\hline
\end{tabular}

Mean \pm SD $(n=5)$. Values in the same row bearing different superscript letters were significantly different $(\mathrm{p}<$ $0.05)$ while values in the same row bearing the same superscript letters were not significantly different $(p>0.05)$.

Table 4 recorded the percentage mean difference between initial and final weight of the rats at the end of the experiment. There was no significant difference in weight gained by rats in all groups

Table 4: Percentage Mean weight of rats (grams)

\begin{tabular}{lllc}
\hline Groups & Initial weight & Final weight & $\begin{array}{c}\text { \%Weight } \\
\text { Difference }\end{array}$ \\
\hline Group 1 (Normal control) & $98.20 \pm 3.11^{\mathrm{a}}$ & $116.20 \pm 6.06^{\mathrm{a}}$ & 15.49 \\
Group 2 (Treatment control) & $11.00 \pm 5.83^{\mathrm{b}}$ & $131.60 \pm 15.52^{\mathrm{a}, \mathrm{b}, \mathrm{c}}$ & 15.65 \\
& & & \\
Group 3 (Standard control) & $120.20 \pm 11.82^{\mathrm{b}}$ & $121.20 \pm 14.96^{\mathrm{a}, \mathrm{b}}$ & 0.89 \\
Group 4 (Experimental group) & $116.80 \pm 14.06^{\mathrm{b}}$ & $135.60 \pm 11.89^{\mathrm{b}, \mathrm{c}}$ & 13.86 \\
Group 5 (Experimental group) & $123.75 \pm 7.41^{\mathrm{b}}$ & $145.50 \pm 9 . .^{44 \mathrm{bc}}$ & 14.95 \\
Group 6 (Experimental group) & $115.50 \pm 4.51^{\mathrm{b}}$ & $135.25 \pm 8.09^{\mathrm{b}, \mathrm{c}}$ & 14.60 \\
\hline
\end{tabular}

Mean \pm SD $(n=5)$. Values in the same row bearing different superscript letters were significantly different $(\mathrm{p}<$ $0.05)$ while values in the same row bearing the same superscript letters were not significantly different $(p>0.05)$.

\section{DISCUSSION}

Different metabolic processes in the body have actually led to formation different molecules, atoms, ions among other biomolecules. Some of these metabolites are beneficial while some are known to be toxic. The radicalized molecules/entities many a time challenge other biomolecule in the body leading to undesirable consequences such as oxidative stress (23). As a result of these consequences, researchers have focused their attention on molecules that can mitigate the deleterious effects of these radicals. Green is a natural beverage that has been reported to possess antioxidant phenolic compounds which are capable of ameliorating the negative effects of free radicals in the body. Hence, the thrust of this work was to investigate the in- vivo effect of green tea on oxidative stress in rats.

Malondialdehyde (MDA) is one of the end products of lipid peroxidation especially that of polyunsaturated fatty acids. An increase in the levels of free radicals in the body leads to the over production of MDA. Malondialdehyde level is a strong biomarker of oxidative stress (24). Its level was significantly increased after the administration of $1500 \mathrm{mg} / \mathrm{kg}$ body weight of paracetamol. This could be as a result of the over production of free radicals and hence lipid peroxidation. However, Green tea consumption at 50,100, $200 \mathrm{mg} / \mathrm{kg}$ bw for seven consecutive days caused a reduction in serum MDA level. As the concentration of green tea was increased from $50 \mathrm{mg} / \mathrm{kg}$ bw to $200 \mathrm{mg} / \mathrm{kg}$ bw, the
MDA concentration gradually reduced. The reduction in MDA level could be linked to decrease in the production of reactive oxygen species (ROS) caused by scavenging activity of the green tea antioxidants. SOD and CAT CAT are the primary cellular defense against oxidative damages. SOD catalyse the dismutation of the superoxide $\left(\mathrm{O}_{2} \mathrm{O}\right)$ radicals into either ordinary molecule oxygen $\left(\mathrm{O}_{2}\right)$ or hydrogen peroxide $\left(\mathrm{H}_{2} \mathrm{O}_{2}\right)$ and prevents further generation of the free radical (25), while converts hydrogen peroxide $\left(\mathrm{H}_{2} \mathrm{O}_{2}\right)$ to water and molecular oxygen and counteracts the disastrous effect of free radicals in the body. SOD and CAT work hand in hand in halting the effect of superoxide $\left(\mathrm{O}_{2} \mathrm{O}\right)$ radicals. In this study, a significant decrease was observed in the activity of SOD enzyme upon the administration of Paracetamol. The excessive production of free radicals as a result of the induction caused a decline in SOD activity as they were overpowered by the radical. However, the administration of green tea led to a boost in the activity of the enzyme and this could be attributed to the high levels of polyphenolic compounds found in green tea. It was observed that CAT activity was significantly higher in the treatment control groups after paracetamol intoxication when compared with the normal control. A similar observation was reported for CAT activity in another study on the Potential hepatoprotective activity of olive leaf extract against carbon tetrachloride by Amani et al. (26). Heikal, Ghanem and Soliman (25) also reported a similar trend for CAT activity in a study on the protective effect of green tea extracts on DNA 
damage in rats. The increased activity of CAT in the paracetamol treated rats probably indicates the protective role the antioxidant system plays in the detoxification of the paracetamol. This could be as a result of the activation of the compensatory mechanism by the antioxidant system.

It is noteworthy that under acute condition of stress induction, most levels of antioxidant parameters rise through physiological mechanism to balance the oxidative stress. Over time the levels of these antioxidants begin to fall if the stressful condition persists. The administration of green tea in this study cause the activity of CAT to significantly $(p<0.05)$ rise again above the level in the normal control. This is to restore the oxidant/antioxidant balance as shown in Table 1.

Glutathione peroxidase (GPx) also plays an important role in protecting tissue from oxidative stress. This enzyme catalyses the reduction of $\mathrm{H}_{2} \mathrm{O}_{2}$ to water and alcohol (26). It is known that at least about three enzymes, namely; glutathione stransferase, glutathione peroxidase and glutathione reductase are involved in mitigating free radical/reactive oxygen challenge. The nonsignificant decrease in glutathione peroxidase recorded in this study might be attributed to a possible challenge to the other two enzymes involved in recycling glutathione peroxidase. Amino acids profile could also account for it. The redox balancing process might have depleted the level of cysteine (one of the three amino acids that make up glutathione peroxidase) in the induced but treated rats (groups 3 to 6). The availability of selenium, a co-factor for glutathione peroxidase might also be responsible. Induction of oxidation with paracetamol and treatment with a high antioxidant sample (green tea) seemed to have depleted selenium levels of the Wistar rats.

Vitamin A is photo-labile. This may partly account for the decrease in its quantity in-vivo as shown in Table 2. The result also suggested that the green tea might not be a good source of vitamin A. This could be because polyphenols in green tea have been reported to have an anti-discolouring effect on $\beta$ carotene which is a precursor of retinal (Vitamin A) (27). This result seems to have been corroborated by the steroid level in this sample. It summarily points that green tea is not lipid-rich. This may also suggest why some people use green tea with milk to possibly augment the nutrients or components that are lacking in it. The maximum increase in vitamin $\mathrm{C}$ concentration recorded in this work is in tandem with classical knowledge. Ascorbic acid has an optimum concentration in vivo at which the best antioxidant activity is expected to be highest, beyond which, it could begin to act as a pro-oxidant. The optimum level was shown at $100 \mathrm{mg} / \mathrm{kg}$ bw of green tea $(0.91 \pm 0.17 \mathrm{mg} / \mathrm{dl})$. The decline in ascorbic acid level of the animals treated with $200 \mathrm{mg} / \mathrm{kg}$ bw green tea may be as a result of exceeding the average optimum in vivo value. Green tea contains vitamin $\mathrm{C}(28)$ and it is believed that taking the right quantity would be beneficial while over-consumption might be deleterious. The levels of vitamin $\mathrm{E}$ observed suggested that the required intake might not have been exceeded. $\alpha$ - tocopherol (vitamin E) is a fatsoluble vitamin which protects cell membrane from oxidative attack. It is a chain breaking antioxidant capable of intercepting peroxyl radicals after which it is oxidized to tocophenryl radical (29). This could explain the slight decrease in serum vitamin $\mathrm{E}$ concentration observed in group 2. The levels of vitamin $\mathrm{E}$ recorded in this work exceeded the levels recorded for vitamin $\mathrm{C}$. This suggests that there might be a great synergistic interaction between the polyphenolics content of green tea and its vitamin C content. Tea polyphenols have been shown to increase the concentration of Vitamin $\mathrm{E}$ and to increase serum antioxidant capacity (28). This finding agreed with the recorded values for vitamin $\mathrm{E}$ in this work as shown in Table 2. The concentration of green tea was directly proportional to the concentration of vitamin $\mathrm{E}$.

Rats treated with green tea did not gain weight at the rate at which the ones which did not receive green tea did even while on the same diet. This probably means that green tea could be used in weight management as claimed by their manufacturers.

\section{CONCLUSION}

From the results of this study, it was concluded that green tea is capable of ameliorating oxidative damages in a biological system. It caused a reduction in serum malondialdehyde (MDA) level and increased some serum enzymatic and nonenzymatic antioxidants.

\section{Ethical Approval}

Institutional ethical clearance was obtained for the study.

Declaration of Interest: There is no conflict of interest to be declared

Availability of Data and Materials: The data and materials used for the research are embedded in the manuscript. The corresponding author will make available the other data on request.

\section{Informed Consent}

Not applicable.

\section{Authors Contribution:}

Ezeja, E. P. is the main researcher who designed and carried out the experiment.

Onuoha, N.O supervised the research.

Ufere, E.A. provided a preliminary review and editing of the work before submission for publication.

Acknowledgment: The researchers of this work wish to acknowledge the German Academic Exchange Service (DAAD) for providing the funding for this work. 


\section{REFERENCES}

1. Mustafa TM, Sura MK, Jassimand, Sarah IA. Free radicals and human health. International Journal of Innovation Sciences. 2015; 4(6):218223.

2. Young I S, Woodside J V. Antioxidants in health and disease. J Clin Pathol. 2001; 54(3):176-186. DOI: 10.1136/jcp.54.3.176.

3. Taibur R, Ismail H, Towhidul I, Hossain U S. Oxidative stress and human health. Advances in Bioscience and Biotechnology. 2012; 3 (7): 997-1019. DOI:10.4236/abb.2012.327123.

4. Chaitanya KV, Pathan AAK, Mazumdar SS, Chak-ravarthi GP, Parine N, Bobbarala V. Role of oxidative stress in human health: An overview. Journal of Pharmacy Research. 2010; 3(6): 1330-1333.

5. Hayden MR, Tyagi SC. Neural redox stress and remodeling in metabolic syndrome, type 2 diabetes. Journal of the Pancreas. 2002; 3(5): 126-138.

6. Takuji S, Monira P, Shingo G, Mamoru I, Yoriyuki N. Beneficial Effects of Tea and the Green Tea Catechin Epigallocatechin-3-gallate on Obesity. Molecules. 2016; 21(10): 1305. DOI: $10.3390 /$ molecules21101305.

7. Wanda CR. An Update on the Health Benefits of Green Tea. Beverages. 2017; 3(1): 6 . DOI:10.3390/beverages3010006.

8. Olaniyi OO, Odeyemi OA, Adewale BD, Oloyede, AA, Anagbogu CF, Adeigbe OO, Adenuga O.O. Tea (Camellia Sinensis) Breeding in Nigeria: Past and Present. International Journal of Scientific and Research Publications. 2014; 4(9): 1-4.

9. Yashin A, Yashin Y, Nemzer B. Determination of antioxidant activity in tea extracts, and their total antioxidant content. American Journal of Biomedical Sciences. 2011; 3(4): 322-335.

10. Naghma K, Hasan M.Tea Polyphenols in Promotion of Human Health. Nutrients; 2018; 11(1):39. DOI: 10.3390/nu11010039.

11. Yamamoto T, Juneja LR, Chu D, Kim M. Chemistry and Applications of Green Tea. Molecules. 2014; 19 (9184): 6-34.

12. Wang $X$, Wu Q, Liu A, Anadón A, Rodríguez JL, Martínez-Larrañaga MR, Yuan Z Martínez MA. Paracetamol: overdose-induced oxidative stress toxicity, metabolism, and protective effects of various compounds in vivo and in vitro. Drug Metab Rev. 2017; 49(4): 395-437.

13. El-Sayed ESM, Mansor AM, Nady ME. Protective effects of pterostilbene against acetaminophen-induced-hepatotoxicity in rats. J. Biochem. Mol. Toxicol. 2015; 29 (1): 35-42.

14. Khan SI, Begum M, Chowdhury R, Rahman M, Asaduzzaman M. Synergistic Hepatoprotective Interaction between $\alpha$ Tocopherol and Ascorbic Acid on Paracetamol Induced Liver Damage in
Rats. Preprints; 2020; (www.preprints.org) doi:10.20944/preprints202006. 0122.v1.

15. Safdar N, Sarfaraz A, Kazmi Z, Yasmin A. Ten different brewing methods of green tea: comparative antioxidant study. J App Biol Biotech. 2016; 4 (3): 33-40. DOI: 10.7324/JABB.2016.40306.

16. Varshney R, Kale RK. Effect of calmodulin antagonists on radiation induced lipid peroxidation in microsomes. International Journal of Radiation Biology. 1990; 58(5): 733-743.

17. Singh G. Chemistry of terpenoids and carotenoids. New Dehli: Discovery Publisher Pvt. Ltd. 2007; 1-286.

18. Fridovich I. Biological effects of superoxide radical. Arch Biochem Biophys.1986; 247(1):1-11. doi: 10.1016/00039861(86)90526-6.

19. Jollow DJ, Mitchell JR, Zampaglione $\mathrm{N}$, Gillette JR. Bromobenzenereactive induced liver necrosis. Protective role of glutathione and evidence for 3, 4-bromobenzene oxide as hepatic metabolite. Pharmacology. 1974; 11(3):151-169.

20. Bassey OA, Lowry OH, Brock MJ, Lopez J A. The determination of vitamin $\mathrm{A}$ and carotene in small quantities of blood serum. J. Biol. Chem. 1946; 166: 177-188.

21. Block G, Dietrich M, Norkus EP, Morrow JD, Hudes M, Caan B, Parker L. Factors associated with oxidative stress in human population. American Journal of Epidemiology. 2002; 156(3): 274-285.

22. Baker H, Frank O, Angelis DB. Plasma tocopherol in man at various times after ingesting free or acetylated tocopherol. Nutr Rep Int. 1980; 21: 531-536.

23. Khatoon M, Islam E, Islam R, Rahman AA, Alam AK, Khondkar P, Rashid M, Parvin S. Estimation of total phenol and in vitro antioxidant activity of Albizia procera leaves. BioMed Central Research Notes. 2013; 6:121. https://doi.org/10.1186/1756-0500-6-121.

24. Khoubnasabjafari M, Ansarin K, Jouyban A. Reliability of malondialdehyde as a biomarker of oxidative stress in psychological disorders. BioImpacts. 2015; 5(3):123-127.

25. Heikal TM, Ghanem HZ, Soliman MS. Protective effect of green tea extract against dimethoate induced DNA damage and oxidant/antioxidant status in male rats. Biohealth Science Bulletin. 2011; 3(1):1-11.

26. Amani A, Anouaa F, Jesus L, Lakdar G, Afoua E, Mohamed SA, Antonio S, Ridha M, David A. Potential hepatoprotective activity of super critical carbon dioxide olive leaf extracts against $\mathrm{CCL}_{4}$-induced liver damage. Foods. 2020; $9(6)$ : $\quad 804$ https://doi.org/10.3390/foods9060804. 
Journal of Dietitians Association of Nigeria (JDAN) Volume 12. December, 2021 Print ISSN: 2141-8209; eISSN: $2635-3326$

27. Uten L, Koketsu M, Kim M. Antidiscolouring activity of green tea polyphenols on $\beta$-carotene. Journal of Agric and Food Chemistry. 1997; 45(6): 2009-2012.

28. Dai F, Chen WF, Zhou, B. Antioxidant synergism of green tea polyphenols with $\alpha$ tocopherol and L-ascorbic acid in SDS micelles. Biochemie. 2008; 90:1499-1505.

29. Vasudevan N, Kow L M, Donald W. Early membrane estrogenic effect required for full expression of slower genomic actions in a nerve cell line. Neurobiology. 2001; 98(21): 1-7. 